Original Article

\title{
Use of antioxidants and time of cold storage: effects over viability parameters and enzymatic levels in semen of rainbow trout (Oncorhynchus mykiss, Walbaum, 1792).
}

\author{
Uso de antioxidantes e tempo de armazenamento a frio: efeitos sobre parâmetros de \\ viabilidade e níveis enzimáticos no sêmen da truta arco-íris (Oncorhynchus mykiss, \\ Walbaum, 1792)
}

\author{
E. Ibáñez-Arancibiaa,b,c (D), J. G. Farías ${ }^{\mathrm{b}}$ (D) and I. Valdebenito ${ }^{\mathrm{c}, \mathrm{d} *}$ (D) \\ aPhD Program in Sciences mentioning Applied Molecular and Cell Biology, La Frontera University, Temuco, Chile \\ bLaboratory of Engineering, Biotechnology and Applied Biochemistry - LIBBA, Department of Chemical Engineering, Faculty of Engineering and \\ Science, La Frontera University, Temuco, Chile \\ 'Department of Agricultural and Aquaculture Sciences, Faculty of Natural Resources, Catholic University of Temuco, Temuco, Chile \\ ${ }^{\mathrm{d} N u c l e u s}$ of Research in Food Production, Faculty of Natural Resources, Catholic University of Temuco, Temuco, Chile
}

\begin{abstract}
The cold storage of milt implies potentials alterations in its quality because the storage generates as main process, free radicals that produce spermatozoa membrane lipids damage with the consequent motility and fertilising capacity disruptions. To decrease the damage generated by free radicals the cells have antioxidant defences (proteins, enzymes, and low molecular weight substances). The objective of the present study evaluated the time storage effect and different antioxidants prepared in spermatic diluents on sperm viability of 0 . mykiss milt stored at $4^{\circ} \mathrm{C}$. The two-way ANOVA denoted that the time storage and antioxidant influence have significant effects separated or combined on viability parameters (sperm motility and viability, proteins concentrations and superoxide dismutase enzymatic activity in seminal plasma). In contrast, only the storage time affected the fertilising capacity and catalase enzymatic activity in seminal plasma. The resulting analysis can conclude that the antioxidant presence improves the viability of cold stored milt, especially the transport conditions and the antioxidants allow the fecundity despite motility decrease.
\end{abstract}

Keywords: superoxide anion, antioxidants, catalase, superoxide dismutase, rainbow trout.

\begin{abstract}
Resumo
O armazenamento a frio de leite implica potenciais alterações em sua qualidade, pois gera como processo principal radicais livres que provocam danos aos lipídios da membrana dos espermatozoides, com as consequentes alterações na motilidade e na capacidade de fertilização. Para diminuir os danos causados pelos radicais livres, as células têm defesas antioxidantes (proteínas, enzimas e substâncias de baixo peso molecular). O presente estudo avaliou o efeito do tempo de armazenamento e diferentes antioxidantes preparados em diluentes espermáticos no armazenamento de viabilidade de 0 . mykiss milt a $4^{\circ} \mathrm{C}$. A ANOVA de duas vias denotou que o armazenamento no tempo e a influência antioxidante têm efeitos significativos separados ou combinados nos parâmetros de viabilidade (motilidade espermática, viabilidade espermática, concentrações de proteínas e atividade enzimática da superóxido dismutase no plasma seminal), enquanto apenas o tempo de armazenamento afetou a capacidade de fertilização e atividade enzimática da catalase no plasma seminal. A análise resultante pode concluir que a presença de antioxidante melhora a viabilidade do leite frio, especialmente as condições de transporte, e os antioxidantes permitem a fecundidade apesar da diminuição da motilidade.
\end{abstract}

Palavras-chave: ânion superóxido, antioxidantes, catalase, superóxido dismutase, truta arco-íris.

\section{Introduction}

The cellular damage generated during the cold storage and the cryopreservation in spermatozoa of freshwater fish has been reported in several studies since it has been directly correlated with low fecundation rates (Merino et al.
2020). Successful storage of semen from salmonids depends on numerous factors, including temperature, fluid volume and gaseous environment. The most widely used method is to conserve them in an atmosphere of $100 \%$ oxygen and at

*e-mail: ivisler@uct.cl.

Received: November 06, 2020 - Aceito January 07, 2021 
low temperatures (Contreras et al. 2019). Storage conditions must ensure the protection of motility, fertilising capacity and maintenance of metabolism to preserve viability and energy sources for sperm activation (Merino et al. 2020). The storage process and cellular metabolism produce free radicals, which cause the oxidation of polyunsaturated fatty acids in the cell membrane and fragmentation of sperm DNA, a process poorly studied in fish (Figueroa et al. 2013).

Free radicals are molecules that have one or more unpaired electrons in their outer orbit (Córdova et al. 2009; Sandoval-Vargas et al. 2020). They are very reactive and unstable and among the reactive oxygen species (ROS), including superoxide anion $\left(\mathrm{O}_{2}^{-}\right)$, hydroxyl $\left(\mathrm{OH}^{-}\right)$ and hydrogen peroxide $\left(\mathrm{H}_{2} \mathrm{O}_{2}\right)$ (Martínez-Álvarez et al. 2005; Sandoval-Vargas et al. 2020). ROS play an essential role in normal sperm physiology (Baker \& Aitken, 2004). The presence of leukocytes in the semen or of abnormal spermatozoa with excessive residual cytoplasm produce high levels of ROS in mammals and fish (Lahnsteiner et al. 2010). The spermatozoa are especially susceptible to peroxidative damage since almost all their cytoplasm is removed during the final stages of spermiogenesis, lacking enzymes that protect against the damage induced by ROS (Lahnsteiner et al. 2010). It generates a reduction in sperm motility and viability (Membrillo et al. 2003). Sperm motility is a crucial prerequisite in determining the quality and fertilizing capacity of spermatozoa (Cosson, 2008).

Compounds that inhibit the excessive production of free radicals or their reactions with biological structures are called antioxidants (Niki, 2010). Aerobic organisms have developed a defensive antioxidant system, which includes molecular and enzymatic defences (Wilhelm Filho, 2007). Among the antioxidant enzymes are superoxide dismutase, catalase, glutathione peroxidase and glutathione reductase (Ritola et al. 2002). The other group is represented by free radical scavenging antioxidant compounds, which are low molecular weight (Lahnsteiner et al. 2010) and can be fat-soluble (antioxidants bound to the cell membrane such as tocopherol or ubiquinol/ubiquinone) or water-soluble (extracellular ascorbate and intracellular glutathione) (Halliwell \& Chirico, 1993). Ciereszko \& Dabrowski (1995), highlight the importance of ascorbic acid as a seminal plasma antioxidant of Oncorhynchus mykiss because its concentration is higher in this than in blood plasma. The proteins present in the seminal plasma would also have an antioxidant role and would be involved in the protection of the integrity of the sperm membrane (lipoproteins) and in the control of proteinases of the reproductive tract or sperm (Ciereszko et al. 2000).

In vitro tests have been carried out with compounds that have antioxidant properties, such as phenols, Trolox $\mathrm{C}$ or ascorbic acid (Lahnsteiner et al. 2011; Ubilla \& Valdebenito, 2011; Faridullah et al. 2015). Phenols have a strong antioxidant action in vitro and inhibit lipoperoxidation by capturing the peroxyl radical (ROO-). An example of this is the use of extracts rich in phenols used to preserve and prolong the shelf life of products made from meats and fish (Tuckey, 2008). The best known are the phenols of red wine [flavonoids (anthocyanins, catechins) and non-flavonoids (stilbenes)] (Fauconneau et al. 1997). Among the stilbenes, resveratrol is one of the best known and is an effective collector of hydroxyl radicals $\left(\mathrm{OH}^{-}\right)$and superoxide anion (Patel and Shah, 2010). In addition to its ability to chelate copper and iron that induce lipoperoxidation (Belguendouz et al. 1998).

Trolox C (6-hydroxy-2,5,7,8-tetramethylchroman-2carboxylic acid) is a water-soluble analogue of $\alpha$-tocopherol and is used as a standard in kinetic studies of many commercial antioxidants (Davies et al. 1988). Ciereszko \& Dabrowski (2000), showed that the in vitro addition of ascorbic acid to trout semen does not protect spermatozoa from damage induced by UV radiation, which generates abnormal embryos.

Primates and teleost fishes cannot synthesise vitamin $C$ because they lost the liver enzyme L-glucono- $\gamma$-lactone oxidase during the evolution (Canyurt \& Akhan, 2008a). This fact could explain why the dietary incorporation of vitamin C is more effective, versus its use in vitro. Canyurt \& Akhan (2008b), confirmed that dietary vitamin E positively affected the quality of sperm regarding concentration, motility and spermatocrit. Blount et al. (2001), observed that dietary supplementation with vitamins $\mathrm{C}$ and $\mathrm{E}$ increases the concentration of these antioxidants in semen, reducing their susceptibility to peroxidation and increases the polyunsaturation of the phospholipids of sperm. Similar effects were observed in the semen of Perca flavescens and Chanos chanos (Ciereszko, 2008).

In the present work, the effect of antioxidants (wine polyphenols, Trolox C and L-ascorbic acid), incorporated in sperm diluent (StopMilt) and cold storage over time, on viability indicators (sperm motility and viability, fertilising capacity, protein concentration, the enzymatic activity of catalase and superoxide dismutase in seminal plasma) was evaluated in semen of rainbow trout (Oncorhynchus mykiss).

\section{Material and Methods}

Experimental design: We worked with specimens of rainbow trout grown in the company Hendrix Genetics Aquaculture S.A. (33 $23^{\circ} 32^{\prime \prime S}$ and $\left.71^{\circ} 40^{\prime} 47^{\prime \prime} W\right)$, in the South of Chile, which matured through artificial photoperiod. The gametes were collected by abdominal massage in January from fourth spawning females and second spawning males.

The semen of four males with motility level 5 according to the scale of Sanchez-Rodriguez \& Billard (1977), was collected. It was mixed to form a pool that was divided into five treatments: Undiluted semen $\left(\mathrm{T}_{1}\right)$; semen diluted in sperm diluent, mark StopMilt (1:2) $\left(\mathrm{T}_{2}\right)$; semen diluted in StopMilt (1:2) plus antioxidants [Grape polyphenols (50\%) $(1 \mathrm{mg} / \mathrm{mL})\left(\mathrm{T}_{3}\right)$; Trolox C $(4 \mu \mathrm{M})\left(\mathrm{T}_{4}\right) ; \mathrm{L}-$ ascorbic acid $(1 \mu \mathrm{M})$ $\left(\mathrm{T}_{5}\right)$ ]. Each treatment was stored for 11 days. The evaluations were repeated every three days after the initial sampling. Each day of sampling a pool of fresh semen undiluted as control (C) was also evaluated. The storage was carried out at $4^{\circ} \mathrm{C}$ in disposable plastic containers with a lid of $200 \mathrm{~mL}$ capacity and maintained in the absence of light, shaken continuously in a shaker, with daily oxygenation.

The storage of the treatments and the evaluations of the viability parameters were carried out in the Reproduction Laboratory (Catholic University of Temuco). The processes of fecundation and incubation were carried out in Hendrix 
Genetics Aquaculture fish farming, so the semen of each treatment should be transferred between these facilities, in expanded polystyrene boxes, at $4^{\circ} \mathrm{C}$ and in the absence of light and with oxygen supplementation.

Evaluation of the duration and level of motility: To an aliquot of $1 \mu \mathrm{L}$ of semen was placed on a slide and to activate motility $10 \mu \mathrm{L}$ of sperm activator (PowerMilt), evaluating immediately the duration of motility with a chronometer until $50 \%$ of the sperm of the visual field was without motility. The measurement was 20 times repeated. The evaluation was performed "blindly" on a Nikon optical microscope model Eclipse E400, using a total magnification of 400X. The level of motility was evaluated in each treatment (10X), for which used the scale proposed by Sanchez-Rodriguez \& Billard (1977), which uses a range of values of 0 for the null flagellar activity and 5 for the maximum activity observed in all the spermatozoa of the visual field.

Fecundation rate: The eggs of four females, of good quality according to morphological parameters described by Valdebenito et al. (2013), were mixed to form a pool. Fecundation was carried out in plastic containers. For each treatment, were used five replicas with a minimum of 150 eggs each. $10 \mathrm{~mL}$ of PowerMilt plus $10 \mu \mathrm{L}$ of semen was added to each replica for the replicas of the undiluted treatment and the control, while $200 \mu \mathrm{L}$ of semen was used for the replicas of the remaining treatments. After 5 minutes, the fertilised eggs were washed several times with water to remove semen. The replicas were placed in coded micro-incubators in open flow systems at a constant temperature of $8^{\circ} \mathrm{C}$.

Fecundation rates were calculated with ova of 140 accumulated thermal units (ATU) using a 10\% acetic acid solution, introducing a random sample of 30 oocytes for 10 minutes for each replicate. All those in which the neural tube was observed, were considered fertilised (Valdebenito et al. 2010).

Determination superoxide anion $\left(\mathrm{O}_{2}^{-}\right)$intracellular: This was established through the technique proposed by De Iuliis et al. (2006) modified, which detects the production of superoxide anion $\left(\mathrm{O}_{2}^{-}\right)$intracellular, through the fluorescent dye dihydroethidium (DHE) which has the peculiarity of accepting superoxide radicals $\left(\mathrm{O}_{2}^{-}\right)$, transforming into 2-hydroxyethyl $\left(2 \mathrm{OHEt}^{+}\right)$, which generates a red nuclear fluorescence. SYTOX Green, a fluorescent stain (green colour), was incorporated to identify the sperm that did not produce $\mathrm{O}_{2}^{-}$.

For the test, DHE and SYTOX Green were diluted in StopMilt to added to aliquots of semen from the different treatments in a final volume of $200 \mu \mathrm{L}$ in concentrations of 2.0 and $0.5 \mu \mathrm{M}$, respectively. In the case of the undiluted treatment and control, aliquots of $5 \mu \mathrm{L}$ of semen and $50 \mu \mathrm{L}$ were used for the remaining treatments.

The cells were incubated in the dark for 15 minutes at $4^{\circ} \mathrm{C}$. Then, in a Nikon brand Eclipse 80i epifluorescence microscope, microphotographs were captured with a Nikon camera model DS-U2, which were analysed with the NIS-Elements AR software.

Determination of proteins and enzymatic activity in seminal plasma: Semen samples from the different treatments were placed in a Thermo Scientific model SL40R centrifuge at $15,000 \mathrm{rpm}$ for $15 \mathrm{~min}$ at $4^{\circ} \mathrm{C}$, to separate the seminal plasma from the sperm.

The supernatant was subjected to the following tests: Quantification of proteins in the seminal plasma according to Bradford (1976); determination of the enzymatic activity of catalase $\left(\mathrm{H}_{2} \mathrm{O}_{2}\right.$ oxide reductase $)$ and superoxide dismutase (SOD) by use of pyrogallol established by Boehringer-Mannheim (1987a,b).

Spermatocrit: Five samples were taken from the initial semen pool, which were arranged in 5 microcapillaries (ca. 90\%) and then sealed with plasticine, to determine the percentage volume of spermatozoa present. These were centrifuged at 10,000 rpm for $10 \mathrm{~min}$ at room temperature, similar to the technique described by Valdebenito et al. (1995).

Statistic analysis: The data were presented as averages \pm standard error. The mode was used to establish the motility level of the semen. For the analysis of the remaining parameters, two-way variance analysis was applied for non-parametric data and the Bonferroni multiple comparisons post-test to identify significant differences in treatments. A value of $\mathrm{p}<0.05$ was set. These statistical analyses were carried out with the Prism program, version 5.0 (Graph Pad Software).

\section{Results}

Sperm motility and spermatocrit: On day $1, \mathrm{~T}_{3}, \mathrm{~T}_{4}$ and $\mathrm{T}_{5}$ recorded the highest motility times $(90.68 \pm 0.29 \mathrm{~s}$, $91.01 \pm 0.26 \mathrm{~s}$ and $90.84 \pm 0.36 \mathrm{~s}$ respectively) and did not show significant differences between them $(\mathrm{p}<0.05)$ (Supplementary Material, Table S1 supplementary material). $\mathrm{T}_{4}$ obtained the highest time significantly $(83.41 \pm 0.23 \mathrm{~s})$, on day 4 ( $\mathrm{p}<0.05)$. No treatment presented flagellar activity on days 8 and 11 (Figure 1). Regarding the

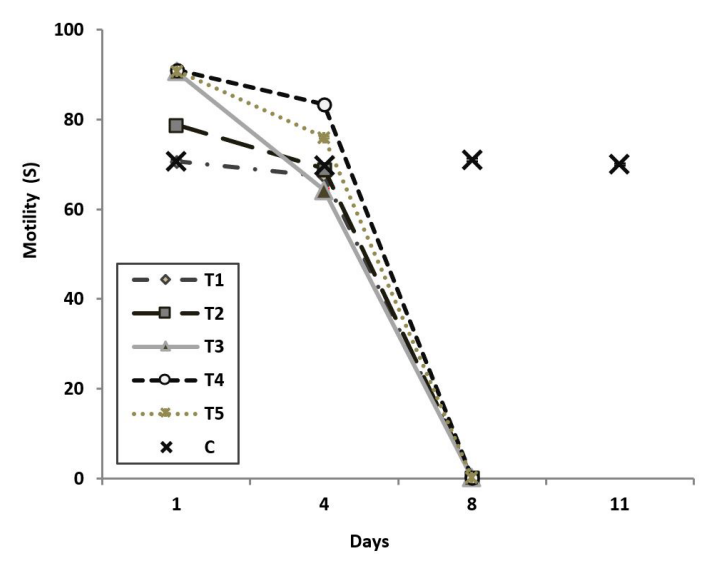

Figure 1. Temporal variation of sperm motility (s) evaluated in rainbow trout (O. mykiss) semen stored at $4^{\circ} \mathrm{C}$ in different treatments and activated with PowerMilt. $\mathrm{T}_{1}$ : undiluted semen, $\mathrm{T}_{2}$ : semen diluted in StopMilt sperm diluent (1:2), and semen diluted in StopMilt (1:2) plus antioxidants $\left[\mathrm{T}_{3}\right.$ : Grape polyphenols (50\%) $(1 \mathrm{mg} / \mathrm{mL}) ; \mathrm{T}_{4}$ : Trolox C $(4 \mu \mathrm{M}) ; \mathrm{T}_{5}$ : L- ascorbic acid $\left.(1 \mu \mathrm{M})\right]$. C: Pool of fresh semen undiluted as control. Average values \pm standard error. 
level of motility, on day 1 , all treatments presented level 5 , while on day $4, \mathrm{~T}_{1}$ presented level 3 and for the remaining treatments, the level was 4 . No treatment presented response on days 8 and 11. The average spermatocrit obtained at the beginning of the experiment was $26.3 \pm 1.3 \%$. The result of the two-way analysis of variance indicates that both storage time and treatments have a significant effect, either combined or separately on sperm motility $(\mathrm{p}<0.05)$.

Fecundation rate: On day 1 and day 4, the treatments did not show significant differences ( $p<0.05$ ) (Table S2 supplementary material). On day 8 , the highest value was significantly $\mathrm{T}_{5}(65.19 \pm 12.97 \%)(\mathrm{p}<0.05)$. On day 11 , the treatments did not show fertilising capacity (Figure 2 ). The result of the two-way analysis of variance indicates that only the storage time has a significant effect on the fertilising capacity ( $\mathrm{p}<0.05$ ).

Determination of superoxide anion $\left(\mathrm{O}_{2}^{-}\right)$intracellular: On day 1 , the treatments did not show significant differences ( $p>0.05$ ) (Table $S 3$ supplementary material). $T_{4}$ had the percentages significantly higher on the remaining days $(90.12 \pm 0,85 \%$ on day $4,87.48 \pm 6.54 \%$ on day 8 and $3.68 \pm 1.62 \%$ on day 11) ( $\mathrm{p}<0.05)$ (Figure 3). The result of the two-way analysis of variance indicates that both storage time and treatments have a significant effect, either combined or separately on sperm viability $(\mathrm{p}<0.05)$.

The concentration of proteins in seminal plasma: $\mathrm{T}_{1}, \mathrm{~T}_{3}$, $\mathrm{T}_{4}$ and $\mathrm{T}_{5}$ did not present significant differences between them on days 1 and 4 ( $p<0.05$ ) (Table S4 supplementary material). On day $8, T_{3}$ and $T_{5}$ exhibited the highest values, showing no significant differences between them (21.52 $\pm 1.18 \mathrm{mg} / \mathrm{mL}$ and $22.60 \pm 0.10 \mathrm{mg} / \mathrm{mL}$ respectively) ( $\mathrm{p}<0.05$ ). On day $11, \mathrm{~T}_{3}$ and $\mathrm{T}_{2}$ showed the highest values, showing no significant differences between them $(19.80 \pm 0.11 \mathrm{mg} / \mathrm{mL}$ and $18.31 \pm 0.03 \mathrm{mg} / \mathrm{mL}$ respectively) $(p<0.05)$ (Figure 4$)$. The result of the two-way analysis of variance indicates that both the storage time and the treatments have a significant effect, either combined or separately on the concentration of proteins in the seminal plasma $(\mathrm{p}<0.05)$.

Enzymatic activity of superoxide dismutase (SOD) in seminal plasma: The average enzymatic activity of SOD evaluated in the seminal plasma of the semen stored in the different treatments are shown in Figure 5. On days 1 and 4, the highest activity values were presented by $\mathrm{T}_{2}, \mathrm{~T}_{3}, \mathrm{~T}_{4}$ and $\mathrm{T}_{5}$, without significant differences between them ( $\mathrm{p}<0.05$ ) (Table S5 supplementary material). On day 8 and 11, the significantly higher values were recorded by $\mathrm{T}_{3}\left(67.69 \pm 0.01 \mathrm{U}^{*} \mathrm{~mL}^{-1 *} \mathrm{~min}^{-1}\right.$ and $59.53 \pm 0.58 \mathrm{U}^{*} \mathrm{~mL}^{-1 *} \mathrm{~min}^{-1}$ respectively) $(\mathrm{p}<0.05)$. The result of the two-way analysis of variance indicates that both the storage time and the treatments have a significant effect, either combined or separately on the enzymatic activity of SOD in the seminal plasma ( $\mathrm{p}<0.05)$.

Enzymatic activity of catalase in seminal plasma: On day 4 , only $T_{1}$ recorded significantly lower activity than the rest of the treatments $\left(2.34 \pm 0.14 \mathrm{U}^{*} \mathrm{~mL}^{-1 *} \mathrm{~min}^{-1}\right)(\mathrm{p}<0.05)$. In the case of days 1, 8 and 11, the treatments did not show significant differences between them $(\mathrm{p}<0.05)$ (Figure 6). The result of the two-way analysis of variance indicates that only the storage time has a significant effect on the

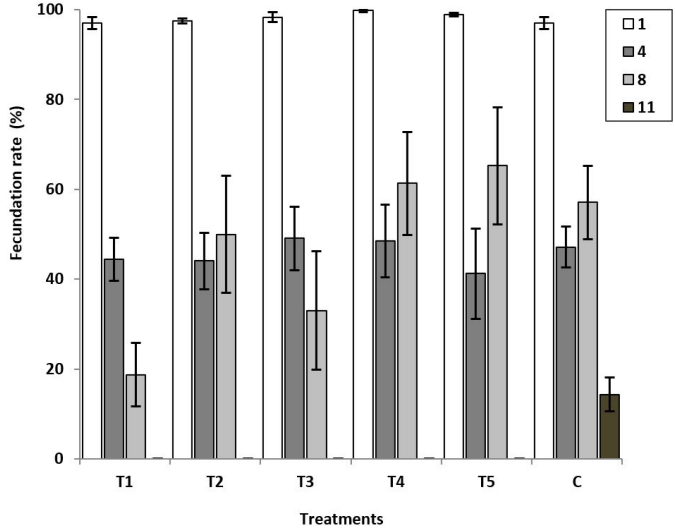

Figure 2. Temporal variation of the fecundation rate (\%) evaluated on days $1,4,8,11$ in rainbow trout (O. mykiss) semen stored at $4^{\circ} \mathrm{C}$ in different treatments and activated with PowerMilt. $\mathrm{T}_{1}$ : undiluted semen, $\mathrm{T}_{2}$ : semen diluted in StopMilt sperm diluent (1:2), and semen diluted in StopMilt $(1: 2)$ plus antioxidants $\left[\mathrm{T}_{3}\right.$ : Grape polyphenols (50\%) $(1 \mathrm{mg} / \mathrm{mL}) ; \mathrm{T}_{4}$ : Trolox C $(4 \mu \mathrm{M}) ; \mathrm{T}_{5}$ : L- ascorbic acid $(1 \mu \mathrm{M})]$. C: Pool of fresh semen undiluted as control. Average values \pm standard error.

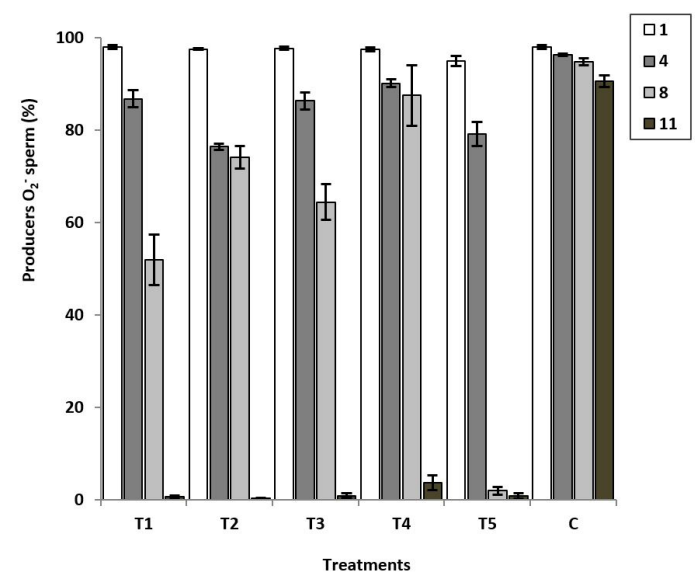

Figure 3. Temporal variation of superoxide anion producing sperm (\%) evaluated on days 1, 4, 8, 11 in rainbow trout (O. mykiss) semen stored at $4^{\circ} \mathrm{C}$ in different treatments. $T_{1}$ : undiluted semen, $\mathrm{T}_{2}$ : semen diluted in StopMilt sperm diluent (1:2), and semen diluted in StopMilt (1:2) plus antioxidants [ $\mathrm{T}_{3}$ : Grape polyphenols (50\%) $(1 \mathrm{mg} / \mathrm{mL}) ; \mathrm{T}_{4}$ : Trolox C $(4 \mu \mathrm{M}) ; \mathrm{T}_{5}$ : L- ascorbic acid $\left.(1 \mu \mathrm{M})\right]$. C: Pool of fresh semen undiluted as control. Average values \pm standard error.

enzymatic activity of catalase in the seminal plasma ( $p<0.05)$ (Table S6 supplementary material).

\section{Discussion}

Sperm motility and spermatocrit: The duration of sperm motility of the treatments for day 1 ranged between $91.01 \pm 0.26 \mathrm{~s}$ for $\mathrm{T}_{4}$ and $70.65 \pm 0.32 \mathrm{~s}$ for $\mathrm{T}_{1}$ and $\mathrm{C}$. This agrees with the values found by Berríos et al. (2010) 


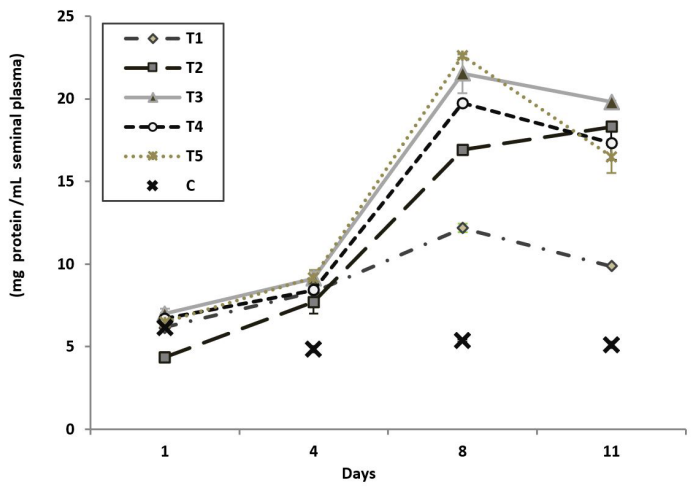

Figure 4. Temporal variation of protein concentration $(\mathrm{mg} / \mathrm{mL})$ evaluated in seminal plasma of rainbow trout (O. mykiss) stored at $4^{\circ} \mathrm{C}$ in different treatments. $\mathrm{T}_{1}$ : undiluted semen, $\mathrm{T}_{2}$ : semen diluted in StopMilt sperm diluent (1:2), and semen diluted in StopMilt (1:2) plus antioxidants $\left[\mathrm{T}_{3}\right.$ : Grape polyphenols $(50 \%)(1 \mathrm{mg} / \mathrm{mL})$; $\mathrm{T}_{4}$ : Trolox C $(4 \mu \mathrm{M}) ; \mathrm{T}_{5}$ : L- ascorbic acid $\left.(1 \mu \mathrm{M})\right]$. C: Pool of fresh semen undiluted as control. Average values \pm standard error.

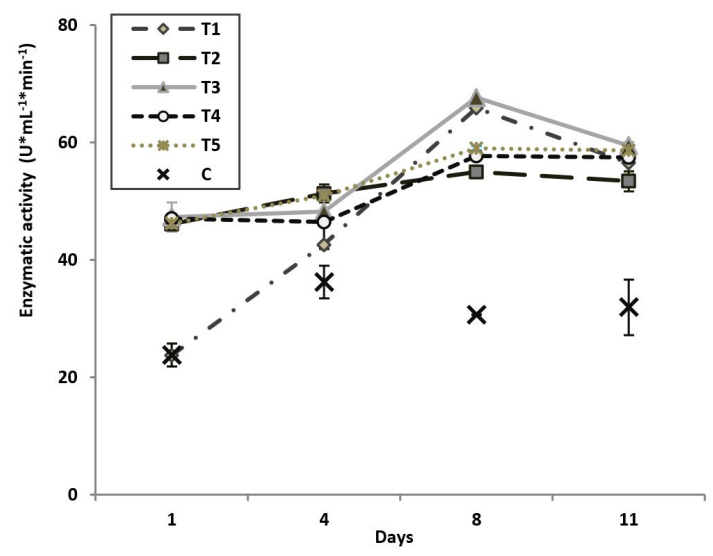

Figure 5. Temporal variation of the enzymatic activity of superoxide dismutase (SOD) $\left(\mathrm{U}^{*} \mathrm{~mL}^{-1 *} \mathrm{~min}^{-1}\right)$ evaluated in seminal plasma of rainbow trout $\left(0\right.$. mykiss) stored at $4^{\circ} \mathrm{C}$ in different treatments. $\mathrm{T}_{1}$ : undiluted semen, $\mathrm{T}_{2}$ : semen diluted in StopMilt sperm diluent (1:2), and semen diluted in StopMilt (1:2) plus antioxidants $\left[\mathrm{T}_{3}\right.$ : Grape polyphenols $(50 \%)(1 \mathrm{mg} / \mathrm{mL}) ; \mathrm{T}_{4}$ : Trolox C $(4 \mu \mathrm{M})$; $\mathrm{T}_{5}$ : L- ascorbic acid $\left.(1 \mu \mathrm{M})\right]$. C: Pool of fresh semen undiluted as control. Average values \pm standard error.

for this day $(1.7 \pm 0.2 \mathrm{~min})$ in 0 . mykiss, although they did not supplement their diluent with antioxidants. However, these values differ from those found by Ubilla \& Valdebenito (2011) in 0. mykiss, because for day 2 they recorded times that varied between $37.07 \pm 0.24 \mathrm{~s}$ for the treatment supplemented with Trolox and $34.04 \pm 0.35 \mathrm{~s}$ for the treatment supplemented with Trolox and polyphenol, while in this study on day 4 , the motility values ranged between $83.41 \pm 0.23 \mathrm{~s}$ for $\mathrm{T}_{4}$ and $64.37 \pm 0.23 \mathrm{~s}$ for T3. These discrepancies are due to the method used (optical microscopy) because although it has advantages such as its simplicity and speed of execution, it has the disadvantage that it depends on the subjectivity of the observer (Varner,

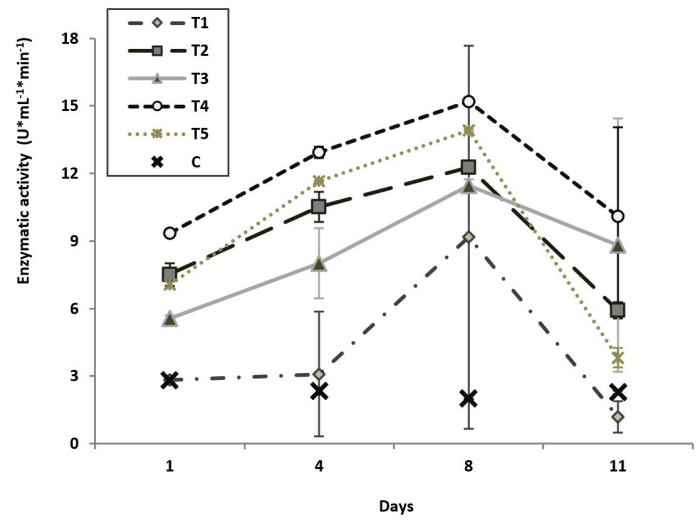

Figure 6. Temporal variation of the enzymatic activity of catalase $\left(\mathrm{U}^{*} \mathrm{~mL}^{-1 *} \mathrm{~min}^{-1}\right)$ evaluated in seminal plasma of rainbow trout (O. mykiss) stored at $4{ }^{\circ} \mathrm{C}$ in different treatments. $\mathrm{T}_{1}$ : undiluted semen, $\mathrm{T}_{2}$ : semen diluted in StopMilt sperm diluent (1:2), and semen diluted in StopMilt (1:2) plus antioxidants $\left[\mathrm{T}_{3}\right.$ : Grape polyphenols (50\%) $(1 \mathrm{mg} / \mathrm{mL}) ; \mathrm{T}_{4}$ : Trolox C $(4 \mu \mathrm{M}) ; \mathrm{T}_{5}$ : L- ascorbic acid $(1 \mu \mathrm{M})]$. C: Pool of fresh semen undiluted as control. Average values \pm standard error.

2008). Finally, the treatments did not show flagellar activity on days 8 and 11. Taking into account the time elapsed before motility was affected, this would not be negatively influenced by intracellular $\mathrm{O}_{2}{ }^{-}$as explained by Berríos et al. (2010). They found no evidence that this radical affected the motility, integrity of the plasma membrane or mitochondrial membrane potential ( $\left.\Delta \Psi^{\mathrm{Mit}}\right)$, the first seven days of storage, which coincided with the collapse of motility on the day 8 (Figure 1). The damage would be due to external factors not evaluated (presence of leukocytes, abnormal sperm, contamination by urine or microorganisms) (Dreanno et al. 1998; Ochsendorf, 1999; Berríos et al. 2010; Sandoval-Vargas et al. 2020). Another factor that could have influenced the loss of motility, after day 7, was the mechanical stress generated by the transport to which the treatments were subjected on sampling days, even though they were transported recreating laboratory conditions (at $4^{\circ} \mathrm{C}$, in darkness and with oxygen supplementation). Ubilla \& Valdebenito (2011), found that supplementation of sperm diluent with vitamin C, Trolox and polyphenol, used in O. mykiss, preserved sperm motility, improved sperm fertilising capacity and increased storage times of sperm (up to 17 days). Although in this work, also the diluent was supplemented with the same antioxidants, these were not able to preserve the motility under the conditions described above.

The average spermatocrit obtained at the beginning of the experiment was $26.3 \pm 1.3 \%$, a value registered almost at the end of the spawning season (first week of January). Sanchez-Rodriguez et al. (1978), found that the spermatocrit in 0 . mykiss did not vary significantly during the spawning season, ranging from $28.3 \%$ at the beginning to $25.4 \%$ at the end. Piironen (1985), found similar values in Salmo salar for spermatocrit, since it varied from $12-13 \%$ during the first third of the spawning period, reaching a maximum value of $27 \%$ at the end of the season. 
Another factor to take into account is the influence of the term of the season on semen quality. Donaldson et al.(2000) reported that semen quality declines with the end of the spawning season for O. mykiss. Ciereszko (2008), reported the decrease in the concentration of sodium, potassium and chloride in the seminal plasma of 0 . mykiss, during the reproductive season, which would be correlated with a poor sperm yield at the end of it. Dabrowski \& Ciereszko (2001), found that the concentration of ascorbate in the seminal plasma of fish is directly affected by dietary vitamin $C$ supplementation and also by the season. As concentrations of ascorbate decline just at the end of the season, since testes atrophy, cells age and apoptosis take place and in 0 . mykiss, the deficiency of this, significantly reduces the concentration of sperm, the total production of sperm throughout the season and sperm motility (Dabrowski \& Ciereszko, 2001).

Fecundation rate: The fertility percentage obtained in the present study (Figure 2) would be similar with literature reports, such as Hoysak \& Liley (2000), who reported that in vitro methods for measuring sperm motility may not reflect what occurs in the presence of oocytes and ovarian fluid. Wojtczak et al. (2007), attributed this to the potential modulating effects of ovarian fluid because when it has a low $\mathrm{pH}$, it is the factor that most negatively influences fecundation.

Several factors determine fertilising success, such as the size of the sperm (Tuset et al. 2008), the content of sodium and calcium in the seminal plasma and its volume (Dziewulska et al. 2008). In fact, the average volume of the seminal plasma at the beginning of the experiment was $73.7 \pm 0.9 \%$, which is in accordance with what Dziewulska et al. (2008), pointing out that the volume of seminal plasma has a considerable effect on sperm motility, determining fertilising success and that its composition for salmonids is considered $50-80 \%$ of the volume of semen.

Another aspect to consider is the quality of the oocytes. The $\mathrm{pH}$, osmolality and protein concentration of the ovarian fluid are key indicators since progressive changes have been observed in them, after ovulation (Lahnsteiner, 2000; Aegerter \& Jalabert, 2004; Rosengrave et al. 2008), in addition to seasonal changes due to changes in the physiological status of the females throughout the spawning season, generating changes in the maturity and quality of the oocytes, influencing the composition of the ovarian fluid (Lahnsteiner et al. 1999; Lahnsteiner, 2000; Aegerter \& Jalabert, 2004; Rosengrave et al. 2009). Aegerter \& Jalabert (2004), associated oocytes of poor quality to ovarian fluid with low $\mathrm{pH} 8$, because at $\mathrm{pH} 7.0$ or 7.8 the activation of motility in spermatozoa of 0 . mykiss does not occur, or its rate is very low (Dietrich et al. 2007; Bobe \& Labbé, 2010; Ciereszko et al. 2010). Lahnsteiner (2000), observed a significant $\mathrm{pH}$ decrease in 0 . mykiss ovarian fluid post-ovulation. Aegerter \& Jalabert (2004), found variations of $0.5 \mathrm{pH}$ units in 0 . mykiss ovarian fluid, due to the temperature change and the time it takes in contact with the air, before its measurement (Rosengrave et al. 2009). Regarding osmolality, a decrease in osmolality in the ovarian fluid can promote premature hydration of the oocyte and therefore low fertility, which is why it is associated with poor quality oocytes (Aegerter \& Jalabert,
2004). Finally, a significant increase in the concentration of ovarian fluid proteins was observed during post-ovulatory ageing (Lahnsteiner et al. 1999; Lahnsteiner, 2000), which was associated with the secretory activity of the post-ovulated ovary more than damaged eggs, product of management or sequential stripping (Aegerter \& Jalabert, 2004; Rosengrave et al. 2009).

Determination of superoxide anion $\left(\mathrm{O}_{2}^{-}\right)$intracellular: On day 1 , the percentage of viable sperm cells $\left(\mathrm{O}_{2}^{-}\right.$producing cells) varied between $97.94 \pm 0.45 \%$ for $\mathrm{T}_{1}$ and $\mathrm{C}$ and $94.95 \pm 1.05 \%$ for $T_{5}$, to decline over the days, through storage time (Figure 3). Berríos et al. (2010), detected a large percentage of intracellular $\mathrm{O}_{2}^{-}$of sperm from the day of semen extraction. However, it was not noticed that this radical affected the motility, integrity of the plasma membrane or mitochondrial membrane potential ( $\left.\Delta \Psi^{\text {Mit }}\right)$, during the first seven days of storage, which coincides with the data obtained in this research. However, Espinoza et al. (2009), showed an inversely proportional correlation between the percentage of spermatozoa with intracellular ROS and the percentage of spermatozoa with progressive motility, normal morphology and sperm viability in humans, and by analysing the correlation between ROS levels and $\Delta \Psi^{\text {Mit }}$ did not find associations between these two events.

Hydroethidine (HE), also known as dihydroethidium (DHE), is a fluorogenic test that has been widely used (Zhao et al. 2003; De Iuliis et al. 2006; Burnaugh et al. 2007; Espinoza et al. 2009; Wilhelm et al. 2009; Berríos et al. 2010), in the detection of intracellular superoxide anion $\left(\mathrm{O}_{2}^{-}\right)$(Zielonka et al. 2009), but the detection of DHE products only by fluorescence has been questioned (Martínez-Pastor et al. 2010).

Hossain et al. (2011), reported that dihydroethidium (hydroethidine) reacts specifically with superoxide anion $\left(\mathrm{O}_{2}^{-}\right)$, as it is freely permeable and oxidised when it binds to DNA, forming yellow 2-hydroxyethyl (567 nm) (Martínez-Pastor et al. 2010). However, other studies have reported that the use of fluorescent filters for the detection of the oxidised DHE product signal confuse the oxidation of DHE to ethidium ( $\mathrm{E}^{+}$, red fluorescence at $617 \mathrm{~nm}$ ), since other oxygen species can also be found, depending on the filters used (Martínez-Pastor et al. 2010; Hossain et al. 2011).

Quantification of proteins in seminal plasma: The protein concentration results obtained in the present study would agree with literature descriptions where protein levels in seminal plasma are highly variable and may have multiple sources of origin (for example, derived directly from blood plasma or secreted by the spermatic duct) (Ciereszko et al. 2000; Peñaranda et al. 2010). There are several hypotheses regarding the role this are playing (Ingermann, 2008).

The concentration of proteins in the seminal plasma of teleost fishes is generally low (1-3 g/L) (Ciereszko et al. 1998; Ciereszko et al. 2000; Lahnsteiner et al. 2004; Dziewulska et al. 2008) and there is a correlation between it and the concentration of sperm (Ciereszko et al. 1998). Sanchez-Rodriguez et al. (1978), found that the highest protein levels in the 0 . mykiss seminal plasma were reached at the beginning of the spawning season (1.74 to $1.89 \mathrm{mg} / \mathrm{mL}$ ), which decreased significantly 
later, reaching a concentration of $0.8 \mathrm{mg} / \mathrm{mL}$ in week 12 . Sanchez-Rodriguez et al. (1978), attributed this drop in protein concentration in the seminal plasma to a sustained increase in sperm production, while Dziewulska et al. (2008) associates this fall with the protective role that proteins would play over sperm, because seminal plasma contains key enzymes for the metabolic process of these. Borchard (1978) established that the average protein concentration in the seminal plasma was $33 \mathrm{mg} / \mathrm{mL}$ in mature males of O. mykiss and Loir et al. (1990) reported that this value fluctuated between 36 to $41 \mathrm{mg} / \mathrm{mL}$ for this parameter, in the same species. They also pointed out that the protein concentration in the seminal plasma is about 20 times lower than the blood serum. Among the seminal plasma peptides, amino acids, lipoproteins, antiproteinases and enzymes are distinguished (Ciereszko et al. 2000).

The composition of the amino acids depends on the degree of maturity, the physiological conditions of each fish and the composition of the diet. These can also be metabolised, since sperm and seminal plasma of salmonids contain powerful enzymes for the metabolism of amino acids (Lahnsteiner, 2009). Ingermann (2008) points out that the level of amino acids in the seminal plasma of O. mykiss varies between $6-14 \mathrm{mg} / \mathrm{mL}$ and suggests that these together with the proteins contribute to the activity of the oxidative metabolism of teleost sperm. It also associates the changes in the amino acid levels of the seminal plasma with the osmoregulation of the spermatozoa. Lahnsteiner (2009) showed that there was a direct effect of amino acids on sperm viability (percentage of sperm motility which can be activated after defined periods of storage), under in vitro conditions. For 0 . mykiss, isoleucine showed a positive effect on sperm viability measured after 48-96 hours of storage. Proline also had a positive effect on it after 4 days of storage. In addition, methionine had a positive effect on it, being detectable after 96 hours of storage. Lahnsteiner (2009), postulated that the existence of methionine and methionine reductase in seminal plasma and spermatozoa of 0 . mykiss indicates that this system would have a key role in the antioxidant defense of fish sperm because the oxidation of methionine protects functionally essential residues of oxidative damage. He also pointed out that in fish semen, branched-chain amino acids (such as isoleucine) are used as additional energy sources during prolonged periods of storage. In the case of proline, its mechanism of action could not be established. Finally, he noted that many amino acid supplements had an adverse effect on sperm viability due to the specific requirements of each species and that they have a dose-dependent effect on sperm viability.

Loir et al. (1990), were able to isolate lipoproteins from seminal plasma ( $33 \mu \mathrm{g} / \mathrm{mL}$ average) identifying them as lipoproteins bound to high density lipids (HDL). They postulated that those would maintain the lipid composition of the spermatic membrane during their stay in the spermatic duct, since that lipoproteins and HDL are the main transporters of biomembrane lipid components in biological fluids (Ciereszko et al. 2000; Peñaranda et al. 2010). Li et al. (2009), attribute to seminal proteins roles in the prolongation and stabilization of sperm viability in teleosts (Ciereszko, 2008; Peñaranda et al. 2010).
The values obtained in our experiment coincide with the variability described for protein concentration. The maximum values found on day 8 for treatments supplemented with antioxidants could be correlated with the role played by seminal proteins in prolonging and maintaining sperm viability (Figure 4).

Although Lahnsteiner et al. (1997), described that in long periods of storage, the lysis of the sperm begins, structurally established by the rupture of the plasma membrane and the disintegration of cellular compounds begins (for example, the storage of spermatozoa in physiological saline solution to inhibit motility for more 24 hours). In addition, after long periods of storage, as well as after other treatments that induce sperm damage [for example, cryopreservation procedures (Figueroa et al. 2013)] or sperm lysis (for example, osmotic resistance tests). Internal compounds, as well as proteins, enzymes, DNA fragments and ions are released and these can be used as indicators of cell damage (Lahnsteiner et al. 1997; Ciereszko, 2008; Li et al. 2009). Glogowski et al. (2000), verified this in rainbow trout semen since there was a significant increase in the activity of the acid phosphatase and the concentration of proteins in the supernatant, which were probably released from the sperm as a result of cryoinjuries produced during cryopreservation. Also, in untreated fresh semen, no indicators of emanation of internal cellular compounds were detected, indicating that the exit of these is a marker of severe damage, lysis or cell necrosis (Lahnsteiner et al. 1997).

Antioxidants: There is little information regarding the in vitro use of antioxidants in the storage of semen from cold-stored fish (Berríos et al. 2010; Lahnsteiner et al. 2010; Lahnsteiner \& Mansour, 2010; Lahnsteiner et al. 2011; Ubilla \& Valdebenito, 2011; Merino et al. 2020; Sandoval-Vargas et al. 2020), because the available data show of improvements in the quality of gametes, when antioxidants are incorporated into the diet (Ciereszko \& Dabrowski, 2000; Dabrowski \& Ciereszko, 2001, Juan et al. 2005; Mansour et al. 2006; Bobe \& Labbé, 2010; Sandoval-Vargas et al. 2020). There are several factors to take into account when evaluating the antioxidant capacity of a compound (Niki, 2010). Although the results showed no significant differences, it was observed that the highest viability values were obtained by $\mathrm{T}_{4}$, followed by $\mathrm{T}_{3}$ and $\mathrm{T}_{5}$. It can be explained by taking into account some factors. The antioxidants free radical scavengers are located in different sites, some intracellular and others in the extracellular environment, in aqueous or lipophilic domains. The effectiveness of the removal of radicals by antioxidants in the membranes and lipoprotein particles depends on physical factors such as the fluidity of the local environment and the mobility of the antioxidant, as well as its chemical reactivity (effect of the Milieu reaction) (Niki, 2010). Also Trolox-C has the same chromatic ring as vitamin $\mathrm{E}$, although it differs in its side chains, it has the same chemical reactivity to free radicals, being consumed in the same rate in homogeneous solutions, but it is consumed more quickly by radicals generated in phase watery (Niki, 2010).

Another important factor is that antioxidants work in specific sites cooperatively. Some antioxidants inhibit the 
oxidation of biological molecules by direct interaction with another antioxidant. Thus, the interaction can result from a synergistic antioxidation, not simply additive. The most efficient interaction is the antioxidant action of vitamin $\mathrm{E}$ and vitamin C (May, 1999; Martínez-Álvarez et al. 2005; Niki, 2010). It was suggested many years ago, and then its importance was demonstrated, especially against lipoperoxidation in LDL, plasma and blood in vitro (Niki, 2010). In the present work, the supplementation of the sperm diluent with vitamin $\mathrm{C}$ improved the antioxidant capacity of $\mathrm{T}_{4}$ due to the synergic effect described above.

The values for $T_{3}$ were lower than those obtained for $T_{4}$. The answer to this lies in the importance of the fate of free radicals derived from antioxidants in the determination of antioxidant capacity. The phenoxyl radical derived from phenolic antioxidants that have hydroquinone and catechol in their structure react rapidly with oxygen to give quinone and hydroxyperoxyl radical, which can induce a new chain reaction (Niki, 2010). It would confirm the trend seen between the data obtained with $\mathrm{T}_{4}$ and $\mathrm{T}_{3}$. In fact, ubiquinol and tocopheryl-hydroquinone are known to undergo autoxidation in vitro. Also, the apparent efficacy of ubiquinol and $\alpha$-tocopheryl-hydroquinone for antioxidation may be lower than that of $\alpha$-tocopherol under certain conditions, although the reactivity of these hydroquinones with free radicals is higher than that of $\alpha$-tocopherol (Niki, 2010). Kennedy et al. (2003), found that resveratrol was a specific inhibitor of cyclooxygenase-1, which decreased sperm motility (38 to $98 \%$ ), when domestic turkey semen was incubated together with the antioxidant $(0.1$ to $10 \mathrm{mM})$, although the toxicity effects of resveratrol or its route of action were not established. Silva et al. (2012), tested the antioxidant effect in vitro of resveratrol and quercetin in sheep spermatozoa cryopreserved and thawed later, concluding that the addition of 5 to $20 \mu \mathrm{g} / \mathrm{mL}$ of resveratrol or quercetin to a diluent Tris-yolk-egg-glycerol reduces the $\Delta \Psi^{\text {Mit }}$

The values for the viability parameters of $T_{5}$ were the lowest concerning $\mathrm{T}_{4}$ and $\mathrm{T}_{3}$. This is due to the fact that vitamin $C$ does not have the same efficacy because of its hydrophilic characteristic, since it removes free radicals primarily in aqueous phase, as the radical removal efficiency of ascorbic acid begins to be lower to the extent that free radicals are deepened inside the membrane or lipoprotein (Niki, 2010). In fact, it has been found that vitamin C in vitro had no effect on the enzymes that prevent lipoperoxidation in cardiac myocytes from guinea pigs (Rojas et al. 1994). It has also been supplemented with vitamin $C$ in vitro, dog semen cryopreserved and thawed later, but did not influence its quality obtaining results similar to the control (Michael et al. 2007). Another effect of vitamin C supplementation in vitro is the protection of the integrity of the membrane. For example, Aurich et al. (1997), found that when using ascorbic acid $(0.45$ and $0.9 \mathrm{~g} / \mathrm{L})$ diluted in diluent with skimmed milk or diluent with glycine in horse semen refrigerated at $5^{\circ} \mathrm{C}$, it was found that it significantly increased the percentage of intact membrane sperm when compared to the control, regardless of the type of diluent. Ciereszko and Dabrowski (2000) found that in vitro supplementation of ascorbic acid in semen from 0 . mykiss does not improve motility or fecundating capacity of semen when fish are fed with diets deficient in ascorbic acid. Vitamin $C$ can also act as a pro-oxidant since in the presence of transition metals, vitamin $C$ generates highly reactive and more destructive radicals, thus generating more free radicals (Dabrowski \& Ciereszko, 2001; Michael et al. 2007; Niki, 2010).

Enzymatic activity of superoxide dismutase (SOD) in seminal plasma: The results obtained show that the enzymatic activity of SOD is higher when the semen is conserved in the diluent and rises much more if it is also supplemented with antioxidants (Figure 5), being $\mathrm{T}_{3}$ the one that presents the highest values of activity. Taubert et al. (2003), reported that phenols derived from plants are known to react with superoxide ion, and its action is similar to SOD, preventing the interaction of nitric oxide with superoxide ion, but failed to establish a cooperative effect in the removal of superoxide ion between antioxidants with different redox potentials. Although the results obtained in the present study could infer a direct interaction between wine polyphenols and the enzymatic activity of SOD, no information was found. Except Sariözkan et al. (2009), who found an inverse interaction between the enzymatic activity of SOD in thawed bull semen and the supplementation of the diluent with bovine serum albumin (BSA) $(5 \mathrm{mg} / \mathrm{mL}), \mathrm{GSH}(2 \mathrm{mM})$ or GGSG (2 mM).

SOD is the first enzyme to respond against free radicals and is one of the ones that offer a greater response to oxidative stress. Any situation that increases consumption by the mitochondria proportionally increases the generation of $\mathrm{O}_{2}$. Experimental tests in animals showed a correlation between SOD and tolerance to oxygen toxicity (Trenzado et al. 2006). Lahnsteiner et al. (2010), found that in both the seminal plasma and brown trout sperm contained different enzymes and metabolites that played a role in antioxidant protection, whereof the enzymes superoxide dismutase had the highest activity and the metabolites, uric acid was found in high concentrations being the main responsible for the protection of sperm under in vivo conditions.

Enzymatic activity of catalase in seminal plasma: The values recorded for catalase enzymatic activity show that it is higher when the semen is conserved with diluent and increases more if it is also supplemented with antioxidants (Figure 6 ), being $\mathrm{T}_{4}$ the one with the highest values of activity. Although the results of this study could infer a direct interaction between Trolox-C and the enzymatic activity of catalase, no information was found, except Sariözkan et al. (2009), found that when supplemented with bovine serum albumin (BSA) $(5 \mathrm{mg} / \mathrm{mL})$ the diluent in which the semen was cryopreserved, an increase in the activity of catalase was observed in the thawed semen. Similarly, Lahnsteiner et al. (2010), showed that uric acid and catalase had a positive effect on sperm viability in brown trout semen at in vitro conditions when these were added to the sperm diluent (catalase $150 \mathrm{U} / \mathrm{L}, 500 \mathrm{U} / \mathrm{L}$, uric acid $0.25 \mathrm{mmol} / \mathrm{L}$, and $0.50 \mathrm{mmol} / \mathrm{L}$ ). Catalase under in vivo conditions in brown trout semen does not play a key role in antioxidant protection, as it does not achieve the necessary enzymatic activity observed under in vitro conditions (Lahnsteiner et al. 2010). Foote \& Hare (2000), 
observed that the motility of rabbit sperm inhibited under oxidative conditions did not improve by the addition of catalase in vitro. In the case of humans, the concentration of catalase in the spermatozoon and in seminal plasma is low, glutathione and glutathione peroxidase are the main hydrogen peroxide scavengers (Lenzi et al. 1996).

In conclusion, the analysis of two-way variances showed that both the storage time and the influence of the antioxidants have significant effects on the parameters of viability (sperm motility and viability, protein concentration and enzyme activity of superoxide dismutase in seminal plasma) and either combined or separately. Except for fertilising capacity and enzymatic activity of catalase in seminal plasma where only the storage time has a significant effect on them. Trolox- $\mathrm{C}\left(\mathrm{T}_{4}\right)$ was the antioxidant that most positively influenced the viability parameters. Regarding the enzymatic activity of superoxide dismutase, the results showed a direct interaction between this and the wine polyphenols $\left(T_{3}\right)$. Finally, the concentration of proteins in the seminal plasma turned out to be a good indicator of the quality of the semen, because high values would reveal emanation of internal cellular compounds, caused by severe damage, lysis or cellular necrosis. In summary, when analysing the results, it can be concluded that the presence of antioxidants improves the viability of cold-stored semen, especially in transport conditions and allowing fecundation, despite the loss of motility. Therefore, future studies should be oriented to in vitro supplementation in cryopreserved semen with antioxidants and establish the concentration, combination and mode of action of these, since under the conditions described above it has been shown that they extend the viability of semen (anti-ageing), ensuring the survival and viability of future embryos.

\section{Acknowledgements}

The authors express their gratitude to Hendrix Genetics Aquaculture S.A. by its collaboration and to the projects FONDEFD10I1064, FONDECYT 1120705, FONDECYT 1180387 and the doctoral scholarship ANID 21191555 for funding this study. Thanks to S.T. and M.I. for your comments.

\section{References}

AEGERTER, S. and JALABERT, B., 2004. Effects of post-ovulatory oocyte ageing and temperature on egg quality and on the occurrence of triploid fry in rainbow trout, Oncorhynchus mykiss. Aquaculture, vol. 231, no. 4/5, pp. 59-71. http://dx.doi. org/10.1016/j.aquaculture.2003.08.019.

AURICH, J., SCHÖNHERR, U., HOPPE, H. and AURICH, C., 1997. Effects of antioxidants on motility and membrane integrity of chilled-stored stallion semen. Theriogenology, vol. 48, no. 2, pp. 185-192. http://dx.doi.org/10.1016/S0093-691X(97)84066-6. PMid:16728118.

BAKER, M. and AITKEN, J., 2004. The importance of redox regulated pathways in sperm cell biology. Molecular and Cellular Endocrinology, vol. 216, no. 1-2, pp. 47-54. http://dx.doi. org/10.1016/j.mce.2003.10.068. PMid:15109744.
BELGUENDOUZ, L., FRÉMONT, L. and GOZZELINO, M., 1998. Interaction of transresveratrol with plasma lipoproteins. Biochemical Pharmacology, vol. 55, no. 6, pp. 811-816. http:// dx.doi.org/10.1016/S0006-2952(97)00544-3. PMid:9586953.

BERRÍOS, O., VALDEBENITO, I., TREULEN, F. and UBILLA, A., 2010. Almacenamiento en frío de espermatozoides de trucha arcoiris (Oncorhynchus mykiss): efectos en la motilidad, superóxido intracelular, integridad de la membrana plasmática y potencial de membrana mitocondrial. Archivos de Medicina Veterinaria, vol. 42, no. 3, pp. 176-186. http://dx.doi.org/10.4067/S0301732X2010000300009.

BLOUNT, J., MOLLER, A.P. and HOUSTON, D.C., 2001. Antioxidants, showy males and sperm quality. Ecology Letters, vol. 4, no. 5, pp. 393-396. http://dx.doi.org/10.1046/j.1461-0248.2001.00255.x.

BOBE, J. and LABBÉ, C., 2010. Egg and sperm quality in fish. General and Comparative Endocrinology, vol. 165, no. 3, pp. 535-548. http://dx.doi.org/10.1016/j.ygcen.2009.02.011. PMid:19272390.

BOEHRINGER-MANNHEIM, 1987a. Enzymes for Routine. Germany: Boehringer Mannheim. Biochemical Information. A revised biochemical reference source, pp. 15-16.

BOEHRINGER-MANNHEIM, 1987b. Enzymes for Routine. Germany: Boehringer Mannheim. Biochemical Information. A revised biochemical reference source, pp. 80-81.

BORCHARD, B., 1978. Studies on the rainbow trout (Salmo gairdneri Rich.). I. Correlation between gonadal development and serum protein pattern. Annales de Biologie Animale, Biochimie, Biophysique, vol. 18, no. 4, pp. 1027-1034. http://dx.doi. org/10.1051/rnd:19780542.

BRADFORD, M., 1976. A rapid and sensitive method for quantitation of microgram quantities of protein utilising the principle of protein-dye binding. Analytical Biochemistry, vol. 72, no. 1/2, pp. 248-254. http://dx.doi.org/10.1016/0003-2697(76)905273. PMid:942051.

BURNAUGH, L., SABEUR, K. and BALL, B., 2007. Generation of superoxide anion by equine spermatozoa as detected by dihydroethidium. Theriogenology, vol. 67, no. 3, pp. 580589. http://dx.doi.org/10.1016/j.theriogenology.2006.07.021. PMid:17045638.

CANYURT, M.A. and AKHAN, S., 2008a. Effect of ascorbic acid supplementation on sperm quality of rainbow trout (Oncorhynchus mykiss). Turkish Journal of Fisheries and Aquatic Sciences, vol. 8, no. 1, pp. 171-175.

CANYURT, M.A. and AKHAN, S., 2008b. Effect of dietary vitamin E on the sperm quality of rainbow trout (Onchorhynchus mykiss). Aquaculture Research, vol. 39, no. 9, pp. 1014-1018. http://dx.doi. org/10.1111/j.1365-2109.2008.01952.x.

CIERESZKO, A., 2008. Chemical composition of seminal plasma and its physiological relationship with sperm motility, fertilising capacity and cryopreservation success in fish. In: S.M.H. ALAVI, J. COSSON, K. COWARD and G. RAFIEE eds. Fish spermatology. Oxford, UK: Alpha Science International Ltd., pp. 215-240.

CIERESZKO, A. and DABROWSKI, K., 1995. Sperm quality and ascorbic acid concentration in rainbow trout semen are affects by dietary vitamin C: an across-season study. Biology of Reproduction, vol. 52, no. 5, pp. 982-988. http://dx.doi. org/10.1095/biolreprod52.5.982. PMid:7626724.

CIERESZKO, A. and DABROWSKI, K., 2000. Effect of ascorbic acid supplement in vitro on rainbow trout sperm viability. Aquaculture International, vol. 8, no. 1, pp. 1-8. http://dx.doi. org/10.1023/A:1009253330451.

CIERESZKO, A., DIETRICH, G., DIETRICH, M., NYNCA, J., KUŹMIŃSKI, H., DOBOSZ, S. and GRUDNIEWSKA, J., 2010. Effects of pH on sperm motility in several Salmoniformes species: Oncorhynchus 
mykiss, Salvelinus fontinalis, Salmo salar and Thymallus thymallus. Journal of Applied Ichthyology, vol. 26, no. 5, pp. 665-667. http:// dx.doi.org/10.1111/j.1439-0426.2010.01536.x.

CIERESZKO, A., GLOGOWSKI, J. and DABROWSKI, K., 2000. Biochemical characteristics of seminal plasma and spermatozoa of freshwater fishes. In: T.R. TIERSCH and P.M. MAZIK, eds. Cryopreservation in aquatic species. Baton Rouge, Louisiana: World Aquaculture Society, pp 20-48.

CIERESZKO, A., PIROS, B., DABROWSKI, K., KUCHARCZYK, D., ŁUCZYŃSKI, M., DOBOSZ, S. and GLOGOWSKI, J., 1998. Serine proteinase inhibitors of seminal plasma of teleost fish: distribution of activity, electrophoretic profiles and relation to proteinase inhibitors of blood. Journal of Fish Biology, vol. 53, no. 6, pp. 1292-1305. http://dx.doi.org/10.1111/j.1095-8649.1998. tb00249.x.

CONTRERAS, P., DUMORNÉ, K., ULLOA-RODRÍGUEZ, P., MERINO, O., FIGUEROA, E., FARÍAS, J., VALDEBENITO, I. and RISOPATRÓN, J., 2019. Effects of short-term storage on sperm function in fish semen: a review. Reviews in Aquaculture, vol. 12, pp. 1373-1389. http://dx.doi.org/10.1111/raq.12387.

CÓRDOVA, A., RUIZ, C., CÓRDOVA, C., CÓRDOVA, M., GUERRA, J. RODRÍGUEZ, B. and ARANCIBIA, K., 2009. Estrés oxidativo y antioxidantes en la conservación espermática. Revista Complutense de Ciencias Veterinarias, vol. 3, no. 1, pp. 1-38.

COSSON, J., 2008. The motility apparatus of fish spermatozoa. In: S.M.H. ALAVI, J. COSSON, K. COWARD and G. RAFIEE, eds. Fish spermatology. Oxford, UK: Alpha Science International Ltd., pp. 281- 316.

DABROWSKI, K. and CIERESZKO, A., 2001. Ascorbic acid and reproduction in fish: endocrine regulation and gamete quality. Aquaculture Research, vol. 32, no. 8, pp. 623-638. http://dx.doi. org/10.1046/j.1365-2109.2001.00598.x.

DAVIES, M., FORNI, L. and WILLSON, R., 1988. Vitamin E analogue Trolox C. E.S.R. and pulse-radiolysis studies of free-radical reaction. The Biochemical Journal, vol. 255, no. 2, pp. 513-522. PMid:2849418.

DE IULIIS, G.N., WINGATE, J.K., KOPPERS, A.J., MCLAUGHLIN, E.A. and AITKEN, R.J., 2006. Definitive evidence for the nonmitochondrial production of superoxide anion by human spermatozoa. The Journal of Clinical Endocrinology and Metabolism, vol. 91, no. 5, pp. 1968-1975. http://dx.doi.org/10.1210/jc.2005-2711. PMid:16507629.

DIETRICH, G.J., WOJTCZAK, M., SŁOWIŃSKA, M., DOBOSZ, S., KUŹMIŃSKI, H. and CIERESZKO, A., 2007. Broken eggs decrease $\mathrm{pH}$ of rainbow trout (Oncorhynchus mykiss) ovarian fluid. Aquaculture (Amsterdam, Netherlands), vol. 73, no. 4, pp. 748-751. http://dx.doi.org/10.1016/j.aquaculture.2007.07.013.

DONALDSON, E., SOLAR, I. and HARVEY, B., 2000. Induced ovulation and spermiation, factors influencing gamete quality. In: T.R. TIERSCH and P.M. MAZIK eds. Cryopreservation in Aquatic Species. Baton Rouge, Louisiana: World Aquaculture Society, pp. 13-19.

DREANNO, C., SUQUET, M., DESBRUYERES, E., COSSON, J., LE DELLIOU, H. and BILLARD, R., 1998. Effect of urine on semen quality in turbot (Psetta maxima). Aquaculture, vol. 169, no. 4 , pp. 247-262. http://dx.doi.org/10.1016/S0044-8486(98)00262-2.

DZIEWULSKA, K., RZEMIENIECKI, A. and DOMAGALA, J., 2008. Basic physico-chemical parameters of milt from sea trout (Salmo trutta $\mathrm{m}$. trutta), brook trout (Salvelinus fontinalis) and rainbow trout (Oncorhynchus mykiss). Journal of Applied Ichthyology, vol. 24, no. 4, pp. 497-502. http://dx.doi.org/10.1111/j.14390426.2008.01133.x.

ESPINOZA, J., SCHULZ, M., SÁNCHEZ, R. and VILLEGAS, J., 2009. Integrity of mitochondrial membrane potential reflects human sperm quality. Andrologia, vol. 41, no. 1, pp. 51-54. http://dx.doi. org/10.1111/j.1439-0272.2008.00878.x. PMid:19143731.

FARIDULLAH, H., EVA, T., PETER, M., ROBERT, S. and NORBERT, L., 2015. Effects of biological active substances to the spermatozoa quality. Journal of Microbiology, Biotechnology and Food Sciences, vol. 5, no. 3, pp. 263-267. http://dx.doi.org/10.15414/ jmbfs.2015/16.5.3.263-267.

FAUCONNEAU, B., WAFFO-TEGUO, P., HUGUET, F., BARRIER, L., DECENDIT, A. and MERILLON, J.M., 1997. Comparative study of radical scavenger and antioxidant properties of phenolic compounds from Vitis vinifera cell cultures using in vitro tests. Life Sciences, vol. 61, no. 21, pp. 2103-2110. http://dx.doi. org/10.1016/S0024-3205(97)00883-7. PMid:9395251.

FIGUEROA, E., RISOPATRÓN, J., SÁNCHEZ, R., ISACHENKO, E., MERINO, O., ISACHENKO, V. and VALDEBENITO, I., 2013. Spermatozoa vitrification of sex-reversed rainbow trout (Oncorhynchus mykiss): effect of seminal plasma on physiological parameters. Aquaculture, vol. 372-375, pp. 119-126. http:// dx.doi.org/10.1016/j.aquaculture.2012.10.019.

FOOTE, R. and HARE, E., 2000. High catalase content of rabbit semen appears to be inherited. Journal of Andrology, vol. 21, no. 5, pp. 664-668. http://dx.doi.org/10.1002/j.1939-4640.2000. tb02134.x. PMid:10975413.

GLOGOWSKI, J., KWASNIK, M., PIROS, B., DABROWSKI, K., GORYCZKO, K., DOBOSZ, S., KUZMINSKI, H. and CIERESZKO, A., 2000. Characterisation of rainbow trout milt collected with a catheter: semen parameters and cryopreservation success. Aquaculture Research, vol. 31, no. 5, pp. 289-296. http://dx.doi. org/10.1046/j.1365-2109.2000.00400.x.

HALLIWELL, B. and CHIRICO, S., 1993. Lipid peroxidation: its mechanism, measurement and significance. The American Journal of Clinical Nutrition, vol. 57, no. 5, (suppl.), pp. 715S-725S. http:// dx.doi.org/10.1093/ajcn/57.5.715S. PMid:8475889.

HOSSAIN, M., JOHANNISSON, A., WALLGREN, M., NAGY, S., SIQUEIRA, A. and RODRIGUEZ-MARTINEZ, H., 2011. Flow cytometry for the assessment of animal sperm integrity and functionality: state of the art. Asian Journal of Andrology, vol. 13, no. 3, pp. 406-419. http://dx.doi.org/10.1038/aja.2011.15. PMid:21478895.

HOYSAK, D.J. and LILEY, N.R., 2000. Fertilisation dynamics in sockeye salmon and a comparison of sperm from alternative male phenotypes. Journal of Fish Biology, vol. 58, no. 5, pp. 12861300. http://dx.doi.org/10.1111/j.1095-8649.2001.tb02286.x.

INGERMANN, R. 2008. Energy metabolism and respiration in fish spermatozoa. In: S.M.H. ALAVI, J. COSSON, K. COWARD, and G. RAFIEE, eds. Fish spermatology. Oxford, UK; Alpha Science International Ltd., pp. 241-266.

JUAN, M.E., GONZÁLEZ-PONS, E., MUNUERA, T., BALLESTER, J., RODRÍGUEZ-GIL, J.E. and PLANAS, J.M., 2005. trans-Resveratrol, a natural antioxidant from grapes, increases sperm output in healthy rats. The Journal of Nutrition, vol. 135, no. 4, pp. 757760. http://dx.doi.org/10.1093/jn/135.4.757. PMid:15795430.

KENNEDY, J., KORN, N. and THURSTON, R., 2003. Prostaglandin levels in seminal plasma and sperm extracts of the domestic turkey, and the effects of cyclooxygenase inhibitors on sperm mobility. Reproductive Biology and Endocrinology, vol. 1, no. 1, pp. 74-80. http://dx.doi.org/10.1186/1477-7827-1-74. PMid:14613550.

LAHNSTEINER, F., 2000. Morphological, physiological and biochemical parameters characterising the over-ripening of rainbow trout eggs. Fish Physiology and Biochemistry, vol. 23, no. 2, pp. 107-118. http://dx.doi.org/10.1023/A:1007839023540.

LAHNSTEINER, F., 2009. The role of free amino acids in semen of rainbow trout Oncorhynchus mykiss and carp Cyprinus carpio. 
Journal of Fish Biology, vol. 75, no. 4, pp. 816-833. http://dx.doi. org/10.1111/j.1095-8649.2009.02317.x. PMid:20738581.

LAHNSTEINER, F. and MANSOUR, N., 2010. A comparative study on antioxidant systems in semen of species of the Percidae, Salmonidae, Cyprinidae and Lotidae for improving semen storage techniques. Aquaculture (Amsterdam, Netherlands), vol. 307, no. 1/2, pp. 130-140. http://dx.doi.org/10.1016/j. aquaculture.2010.07.011.

LAHNSTEINER, F., MANSOUR, N. and BERGER, B., 2004. Seminal plasma proteins prolong the viability of rainbow trout (Oncorhynchus mykiss) spermatozoa. Theriogenology, vol. 62, no. 5, pp. 801-808. http://dx.doi.org/10.1016/j. theriogenology.2003.12.001. PMid:15251231.

LAHNSTEINER, F., MANSOUR, N. and KUNZ, F., 2011. The effect of antioxidants on the quality of cryopreserved semen in two salmonid fish, the brook trout (Salvelinus fontinalis) and the rainbow trout (Oncorhynchus mykiss). Theriogenology, vol. 76, no. 5, pp. 882-890. http://dx.doi.org/10.1016/j. theriogenology.2011.04.019. PMid:21705054.

LAHNSTEINER, F., MANSOUR, N. and PLAETZER, K., 2010. Antioxidant systems of brown trout (Salmo trutta f. fario) semen. Animal Reproduction Science, vol. 119, no. 3/4, pp. 314-321. http:// dx.doi.org/10.1016/j.anireprosci.2010.01.010. PMid:20171027.

LAHNSTEINER, F., WEISMANN, T. and PATZNER, R.A., 1997. Aging processes of rainbow trout semen during storage. Progressive Fish-Culturist, vol. 59, no. 4, pp. 272-279. http://dx.doi. org/10.1577/1548-8640(1997)059<0272:APORTS>2.3.CO;2.

LAHNSTEINER, F., WEISMANN, T. and PATZNER, R., 1999. Physiological and biochemical parameters for egg quality determination in lake trout, Salmo trutta lacustris. Fish Physiology and Biochemistry, vol. 20, no. 4, pp. 375-388. http://dx.doi. org/10.1023/A:1007715621550.

LENZI, A., PICARDO, M., GANDINI, L. and DONDERO, F., 1996. Lipids of the sperm plasma membrane: from polyunsaturated fatty acids considered as markers of sperm function to possible scavenger therapy. Human Reproduction Update, vol. 2, no. 3, pp. 246-256. http://dx.doi.org/10.1093/humupd/2.3.246. PMid:9079417.

LI, P., HULAK, M. and LINHART, O., 2009. Sperm proteins in teleostean and chondrostean (sturgeon) fishes. Fish Physiology and Biochemistry, vol. 35, no. 4, pp. 567-581. http://dx.doi. org/10.1007/s10695-008-9261-y. PMid:18810648.

LOIR, M., LABBE, C., MAISSE, G., PINSON, A., BOULARD, G., MOUROT, B. and CHAMBEYRON, F., 1990. Proteins of seminal fluid and spermatozoa in the trout (Oncorhynchus mykiss): partial characterisation and variations. Fish Physiology and Biochemistry, vol. 8, no. 6, pp. 485-495. http://dx.doi.org/10.1007/BF00003405. PMid:24221035.

MANSOUR, N., MCNIVEN, M. and RICHARDSON, G., 2006. The effect of dietary supplementation with blueberry, $\alpha$-tocopherol or astaxanthin on oxidative stability of Artic char (Salvelinus alpinus) semen. Theriogenology, vol. 66, no. 2, pp. 373-382. http://dx.doi.org/10.1016/j.theriogenology.2005.12.002. PMid:16420960.

MARTÍNEZ-ÁLVAREZ, R., MORALES, A. and SANZ, A., 2005. Antioxidant defenses in fish: biotic and abiotic factors. Reviews in Fish Biology and Fisheries, vol. 15, no. 1-2, pp. 75-88. http:// dx.doi.org/10.1007/s11160-005-7846-4.

MARTÍNEZ-PASTOR, F., MATA-CAMPUZANO, M., ÁLVAREZRODRÍGUEZ, M., ÁLVAREZ, M., ANEL, L., and DE PAZ, P., 2010. Probes and techniques for sperm evaluation by flow cytometry. Reproduction of Domestic Animals, vol. 45, pp. 67-78. http:// dx.doi.org/10.1111/j.1439-0531.2010.01622.x.
MAY, J.M., 1999. Is ascorbic acid an antioxidant for the plasma membrane? The FASEB Journal, vol. 13, no. 9, pp. 995-1006. http://dx.doi.org/10.1096/fasebj.13.9.995. PMid:10336882.

MEMBRILLO, A., CÓRDOVA, A., HICKS, J., OLIVARES, I., MARTÍNEZ, V. and VALENCIA, J., 2003. Peroxidación lipídica y antioxidantes en la preservación de semen. Una revisión. Interciencia, vol. 28, no. 12, pp. 699-704.

MERINO, O., DUMORNÉ, K., LEIDY, S.V., FIGUEROA, E., VALDEBENITO, I., FARÍAS, J.G. and RISOPATRÓN, J., 2020. Short-term storage sperm of coho salmon (Oncorhynchus kisutch) at $4{ }^{\circ} \mathrm{C}$ : Effect of sperm: Extender dilution ratios and antioxidant butylhydroxytoluene (BHT) on sperm function. Cryobiology, vol. 95, pp. 44-50. http://dx.doi.org/10.1016/j.cryobiol.2020.06.007. PMid:32554155.

MICHAEL, A., ALEXOPOULOS, C., PONTIKI, E., HADJIPAVLOU-LITINA, D., SARATSIS, P. and BOSCOS, C., 2007. Effect of antioxidant supplementation on semen quality and reactive oxygen species of frozen-thawed canine spermatozoa. Theriogenology, vol. 68, no. 2, pp. 204-212. http://dx.doi.org/10.1016/j. theriogenology.2007.04.053. PMid:17540441.

NIKI, E., 2010. Assessment of antioxidant capacity in vitro and in vivo. Free Radical Biology \& Medicine, vol. 49, no. 4, pp. 503515. http://dx.doi.org/10.1016/j.freeradbiomed.2010.04.016. PMid:20416370.

OCHSENDORF, F., 1999. Infections in the male genital tract and reactive oxygen species. Human Reproduction Update, vol. 5, no. 5, pp. 399-420. http://dx.doi.org/10.1093/humupd/5.5.399. PMid: 10582780.

PEÑARANDA, D.S., MARCO-JIMENEZ, F., PÉREZ, L., GALLEGO, V., MAZZEO, L., JOVER, M. and ASTURIANO, J.F., 2010. Protein profile study in European eel (Anguilla Anguilla) seminal plasma and its correlation with sperm quality. Journal of Applied Ichthyology, vol. 26, no. 5, pp. 746-752. http://dx.doi.org/10.1111/j.14390426.2010.01540.x.

PIIRONEN, J., 1985. Variation in the properties of milt from the finnish landlocked salmon (Salmo salar M. Sebago Girard) during a spawning season. Aquaculture, vol. 48, no. 3/4, pp. 337-350. http://dx.doi.org/10.1016/0044-8486(85)90136-X.

RITOLA, O., LIVINGSTONE, D., PETERS, L. and LINDSTRÖM-SEPPÄ, P., 2002. Antioxidant processes are affected in juvenile rainbow trout (Oncorhynchus mykiss) exposed to ozone and oxygensupersaturated water. Aquaculture (Amsterdam, Netherlands), vol. 210, no. 3/4, pp. 1-19. http://dx.doi.org/10.1016/S00448486(01)00823-7.

ROJAS, C., CADENAS, S., PÉREZ-CAMPO, R., LÓPEZ-TORRES, M. and BARJA, G., 1994. Effect of vitamin C on antioxidants, lipid peroxidation and GSH system in the normal guinea pig heart. Journal of Nutritional Science and Vitaminology, vol. 40, no. 5, pp. 411-420. http://dx.doi.org/10.3177/jnsv.40.411. PMid:7891202.

ROSENGRAVE, P., GEMMELL, N., METCALF, V., MCBRIDE, K. and MONTGOMERIE, R., 2008. A mechanism for cryptic female choice in chinook salmon. Behavioral Ecology, vol. 19, no. 6, pp. 1179-1185. http://dx.doi.org/10.1093/beheco/arn089.

ROSENGRAVE, P., TAYLOR, H., MONTGOMERIE, R., METCALF, V., MCBRIDE, K. and GEMMELL, N., 2009. Chemical composition of seminal and ovarian fluids of chinook salmon (Oncorhynchus tshawytscha) and their effects on sperm motility traits. Comparative Biochemistry and Physiology. Part A, Molecular E Integrative Physiology, vol. 152, no. 1, pp. 123-129. http://dx.doi. org/10.1016/j.cbpa.2008.09.009. PMid:18835457.

SANCHEZ-RODRIGUEZ, M., and BILLARD, R., 1977. Conservation de la motilité et du pouvoir fécondant du sperme de truite arc- 
en-ciel maintenu à des températures voisines de $0{ }^{\circ} \mathrm{C}$. Bulletin Francais de la Peche et de la Pisciculture, vol. 265, pp. 143-152.

SANCHEZ-RODRIGUEZ, M., ESCAFFRE, A.-M., MARLOT, S. and REINAUD, P., 1978. The spermiation period in the rainbow trout (Salmo gairdneri). Plasma gonadotropin and androgen levels, sperm production and biochemical changes in the seminal fluid. Annales de Biologie Animale, Biochimie, Biophysique, vol. 18, no. 4, pp. 943-948. http://dx.doi.org/10.1051/rnd:19780529.

SANDOVAL-VARGAS, L., SILVA JIMENEZ, M., RISSOPATRON GONZÁLEZ, J., FIGUEROA VILLALOBOS, E. and VALDEBENITO ISLER, I., 2020. Oxidative stress and use of antioxidants in fish semen cryopreservation. Reviews in Aquaculture. http://dx.doi. org/10.1111/raq.12479.

SARIÖZKAN, S., TUNCER, P.B., BUCAK, M.N. and ULUTAŞ, P.A., 2009. Influence of various antioxidants on microscopic-oxidative stress indicators and fertilising ability of frozen-thawed bull semen. Acta Veterinaria Brno, vol. 78, no. 3, pp. 463-469. http:/ dx.doi.org/10.2754/avb200978030463.

PATEL, J.A. and SHAH, P.K., 2010. Resveratrol and its biological actions. International Journal of Green Pharmacology, vol. 4, no. 1, pp. 15-21. http://dx.doi.org/10.4103/0973-8258.62160.

SILVA, E., CAJUEIRO, J., SILVA, S., SOARES, P. and GUERRA, M., 2012. Effects of antioxidants resveratrol and quercetin on in vitro evaluation of frozen ram sperm. Theriogenology, vol. 77, no. 8, pp. 1722-1726. http://dx.doi.org/10.1016/j. theriogenology.2011.11.023. PMid:22289215.

TAUBERT, D., BREITENBACH, T., LAZAR, A., CENSAREK, P., HARLFINGER, S., BERKELS, R., KLAUS, W. and ROESEN, R., 2003. Reaction rate constants of superoxide scavenging by plant antioxidants. Free Radical Biology $\mathcal{E}$ Medicine, vol. 35, no. 12, pp. 1599-1607. http://dx.doi.org/10.1016/j. freeradbiomed.2003.09.005. PMid:14680683.

TRENZADO, C., HIDALGO, M., GARCÍA-GALLEGO, M., MORALES, A., FURNÉ, M., DOMEZAIN, A., DOMEZAIN, J. and SANZ, A., 2006. Antioxidant enzymes and lipid peroxidation in sturgeon Acipenser naccarii and trout Oncorhynchus mykiss. A comparative study. Aquaculture (Amsterdam, Netherlands), vol. 254, no. 1/4, pp. 758-767. http://dx.doi.org/10.1016/j.aquaculture.2005.11.020.

TUCKEY, N., 2008. Technologies for tissue preservation: the role of endogenous and exogenous antioxidants in preserving tissue function in Chinook salmon, Oncorhynchus tshawytscha. New Zealand; University of Canterbury, 146 p. Doctoral thesis

TUSET, V., DIETRICH, G., WOJTCZAK, M., SLOWIŃSKA, M., DE MONSERRAT, J. and CIERESZKO, A., 2008. Relationships between morphology, motility and fertilisation capacity in rainbow trout (Oncorhynchus mykiss) spermatozoa. Journal of Applied Ichthyology, vol. 24, no. 4, pp. 393-397. http://dx.doi. org/10.1111/j.1439-0426.2008.01145.x.
UBILLA, A. and VALDEBENITO, I., 2011. Use of antioxidants on rainbow trout Oncorhynchus mykiss (Walbaum, 1792) sperm diluents: effects on motility and fertilising capability. Latin American Journal of Aquatic Research, vol. 39, no. 2, pp. 338-343. http://dx.doi.org/10.3856/vol39-issue2-fulltext-15.

VALDEBENITO, I., BARILE, J., VEGA, R., DANTAGNAN, P., BÓRQUEZ, A. and CARREÑO, E., 1995. Análisis cualitativo y cuantitativo del semen de puye Galaxias maculatus (Jenyns, 1842) (Salmoniformes: galaxiidae). Biologia Pesquera, vol.24, pp. 17-21.

VALDEBENITO, I., MORENO, C., LOZANO, C. and UBILLA, A., 2010. Effect of L-glutamate and glycine incorporated in activation media, on sperm motility and fertilisation rate of rainbow trout (Oncorhynchus mykiss) spermatozoa. Journal of Applied Ichthyology, vol. 26, no. 5, pp. 702-706. http://dx.doi.org/10.1111/ j.1439-0426.2010.01555.x.

VALDEBENITO, I., GALLEGOS, P. and EFFER, B., 2013. Gamete quality in fish: evaluation parameters and determining factors. Zygote (Cambridge, England), vol. 23, no. 2, pp. 1-21. http://dx.doi. org/10.1017/S0967199413000506. PMid:24229714.

VARNER, D.D., 2008. Developments in stallion semen evaluation. Theriogenology, vol. 70, no. 3, pp. 448-462. http://dx.doi. org/10.1016/j.theriogenology.2008.04.023. PMid:18495237.

WILHELM, J., VYTÁŠEK, R., OŠŤÁDALOVÁ, I. and VAJNER, L., 2009. Evaluation of different methods detecting intracellular generation of free radicals. Molecular and Cellular Biochemistry, vol. 328, no. 1/2, pp. 167-176. http://dx.doi.org/10.1007/s11010009-0086-5. PMid:19301099.

WILHELM FILHO, D., 2007. Reactive oxygen species, antioxidants and fish mitochondria. Frontiers in Bioscience, vol. 12, no. 1, pp. 1229-1237. http://dx.doi.org/10.2741/2141. PMid:17127376.

WOJTCZAK, M., DIETRICH, G.J., SŁOWIŃSKA, M., DOBOSZ, S., KUŹMIŃSKI, H. and CIERESZKO, A., 2007. Ovarian fluid pH enhanced motility parameters of rainbow trout (Oncorhynchus mykiss) spermatozoa. Aquaculture (Amsterdam, Netherlands), vol. 270, no. 1/4, pp. 259-264. http://dx.doi.org/10.1016/j. aquaculture.2007.03.010.

ZHAO, H., KALIVENDI, S., ZHANG, H., JOSEPH, J., NITHIPATIKOM, K., VÁSQUEZ-VIVAR, J. and KALYANARAMAN, B., 2003. Superoxide reacts with hydroethidine but forms a fluorescent product that is distinctly different from ethidium: potential implications in intracellular fluorescence detection of superoxide. Free Radical Biology \& Medicine, vol. 34, no. 11, pp. 1359-1368. http://dx.doi. org/10.1016/S0891-5849(03)00142-4. PMid:12757846.

ZIELONKA, J., HARDY, M. and KALYANARAMAN, B., 2009. HPLC study of oxidation products of hydroethidine in chemical and biological systems: ramifications in superoxide measurements. Free Radical Biology \& Medicine, vol. 46, no. 3, pp. 329-338. http://dx.doi. org/10.1016/j.freeradbiomed.2008.10.031. PMid:19026738. 


\section{Supplementary Material}

Supplementary material accompanies this paper.

S1. Supplementary material of the article "Use of antioxidants and time of cold storage: effects over viability parameters and enzymatic levels in semen of rainbow trout (Oncorhynchus mykiss, Walbaum, 1792)".

This material is available as part of the online article from http://www.scielo.br/BJB 